\title{
PRESERVATION OF ROTTERDAM FORT POST BONGAYA AGREEMENT IN MAKASSAR
}

\author{
Nurul Fadilah ${ }^{1}$ \\ M. Dahlan $\mathbf{M}^{2}$ \\ Syamzan Syukur ${ }^{3}$ \\ Alauddin State Islamic University of Makassar 1,2,3 \\ nurulfadilah226@gmai.com
}

\begin{abstract}
The purpose of this study was to clear analyze the existence of Fort Rotterdam and its preservation after the Bongaya agreement in Makassar. This study uses the steps in writing history, namely heuristics, criticism, interpretation and becomes a historiographical work with the literature study method. The results of this study indicate that First, Ujung Pandang Fortress have built by the Kingdom of Gowa to defend the greatness and dignity of the Gowa kingdom from colonial threats. This fort is one of the guard forts of the main fortress of Somba Opu, which is the center of the Kingdom of Gowa. After the Gowa kingdom lost the Makassar war and confirmed by the Bongaya Agreement on 18 November 1667, the Ujung Pandang fort fell into the hands of the VOC (Netherlands Indies Trade Association) and changed its name to Fort Rotterdam and as a spice-trading center from east to west. Second, the preservation of the fort after the Bongaya Agreement, namely during the Japanese occupation. The fort have used as a center for language and agricultural research activities, after that in 1973 after independence the fort changed its function as the National Institute of Antiquities and Heritage, which is currently known as the Cultural Heritage Conservation Center and Museum La Galigo.
\end{abstract}

\section{Keyword: Preservation; Rotterdam; Bongaya}

\section{INTRODUCTION}

The long journey of the Indonesian State during colonialism to independence, left various evidences that can still be witnessed today, both physical and non-physical. Non-physical relics can be interpreted as cultural, religious or food relics, while physical remains can be in the form of buildings or historical objects scattered throughout Indonesia. Historic buildings and objects have economic value if the government and related parties are able to manage them as tourist destinations. Article 88 paragraph 1 of Law Number 11 Year 2010 explains that the Government, Regional Government, and everyone can take advantage of cultural heritage for the interests of religion, social, education, science, technology, culture and tourism.

In connection with its utilization, cultural heritage can be developed into a tourist attraction that raises historical values, architecture, and others. Cultural heritage can also be used as a source of historical learning which is very useful in learning as well as introducing to all people about the journey of the nation's struggle.

One of the best preserved cultural sites is the Rotterdam Fortress. Fort Rotterdam is also known as Fort Rotterdam or Fortress Ujung Pandang. Ujung Pandang Fortress, is one of the historical relics of the mighty Gowa Kingdom which was a very strong and successful kingdom in the XVII century, with its business city Makassar is 
one of the Dutch forts that were built in Indonesia and is still preserved to this day and even Barbara Crossette in New The York Times described it as "the best preserved Dutch fort in Asia"1. Ujung Pandang Fortress was built for the first time by the King of Gowa $\mathrm{X}$ named Imanrigau Daeng Bonto Karaeng Lakiung or Karaeng Ulaweng in 1545. The fort is located near the coast with the shape of a turtle, this is in accordance with the philosophy of the Kingdom of Gowa at that time because turtles can live in the sea as well as land with the meaning that the Kingdom of Gowa triumphed on land and at sea so that the surrounding community recognized this fort as the panyyua fort (turtle) ${ }^{2}$.

Ujung Pandang Fortress was built to defend the greatness and dignity of the Gowa kingdom from the colonial threat. This fort is one of the guard forts from the main fort of Somba Opu which is the center of the Gowa Kingdom. After the Gowa kingdom lost the battle of Makassar and was strengthened by the Bongaya Treaty of November 18, 1667, the Ujung Pandang fort fell into the hands of the VOC (Dutch East Indies Trade Association) and changed its name to Fort Rotterdam.

Therefore, the authors are interested in conducting research to further analyze the importance of the Fort Rotterdam fort site as a historical destination and its preservation after the Bongaya agreement in Makassar.

Based on the description above, the aim of the research in this article is to find out how Fort Rotterdam is used as the main destination for historical destination activities and its preservation in Makassar.

\section{RESEARCH METHOD}

In an effort to collect data, the author moved on the basis of this research, namely historical research. So at least the method used is the historical research method which is a set of systematic rules and principles. The steps in writing history are heuristics (observation, interview and documentation), criticism, interpretation and become a historiographical work that is easy to understand for every reader using the library study method.

After going through the data collection process, the next step is the step in data processing. In processing data, the authors remain consistent in the use of the historical research method stages, namely at the data validation stage or verification of the validity of data sources. This stage is known as external criticism and internal criticism.

At the data analysis stage, it is expected to be able to present data as the final form of reporting research data. In reporting this research, once again using historical research methods in general. However, it needs to be described with the model contained in the research method tools in general. Thus, in addition to interpreting methods and historiography, it is also necessary to elaborate the approach used. So that the understanding of existing historical data uses a holistic analysis. Furthermore, the data analysis methods will be described as follows;

\footnotetext{
${ }^{1}$ Nuraeda, dkk., Album Sejarah dan Kepurbakalan Sul-Sel Wisata Kultural Historis (Makassar: Dinas Kebudayaan dan Pariwisata Provinsi Sul-Sel, 2008), h. 3.

${ }^{2}$ Risang. A dan Dhani Mutiari, Karakteristik Benteng Vastenberg sebagai Bangunan Heritage di Surakarta, (journal UMS, 2018), h. 26.
} 


\section{a. Interpretation}

This stage is a stage that requires accuracy and an objective attitude to assess a verified source to become a fact.

b. Approach

As an effort to interpret data sources, this step certainly requires a multidisciplinary approach in understanding the object of study. The approach used is as follows:

1. Historical approach

2. Archaeological approach

3. Sociological approach

4. Cultural anthropological approach

The last stage of this research is historiography. At this stage, the author will present the results of the research, or rather the results of verification and interpretation of historical facts.

\section{RESULT AND DISCUSSION}

\section{A. The existence of Fort Rotterdam}

Ujung Pandang Fortress is called Ujung Pandang Fortress because it is located at the end where many pandanus grow ${ }^{3}$. Ujung Pandang Fortress or known as Fort Rotterdam together with other forts stand majestically along the coast of the Kingdom of Gowa. The fort was a symbol of the greatness and glory of the Gowa Kingdom in its era. Even now, Ujung Pandang Fortress is still intact even though it is more than 4 centuries old and is a clear proof of the existence of the Gowa Kingdom.

Ujung Pandang Fortress is one of the guard fortresses (protectors) of the main fortress, namely Somba Opu Fortress, which has survived the destruction until now. Other forts such as Kale Gowa Fortress, Tallo Fortress, Sanro Bone Fortress, Barombong Fortress, Mariso, Ujung Tanah, Bontorannu Fortress, Panakkukang Fortress, Bayoa Fortress, Garassi Fortress, Ana Gowa Fortress and Galesong Fortress are all in name only. ${ }^{4}$. Ujung Pandang Fortress was founded in 1543-1565.

The fort was built with a Portuguese architect, it is said that because the development of the Gowa people at that time had many contacts with the Portuguese,

${ }^{3}$ Kantor Cabang II Lembaga Sejarah dan Antropologi Ujung pandang (Benteng Rotterdam) h. 1. La Side, majalah bingkisan no 19 tahun I Yayasan Kebudayaan Sulawesi Selatan/Tenggara, 15 Mei 1968 h. 31. La Side menulis sebagai berikut "Adapun nama Benteng Ujung Pandang yang dalam sebutan Makassar berubah menjadi Jumpandang di peroleh karena dibangun pada sebuah ujung yang penuh dengan pohon pandan atau nenas".

Valentjn francois, verhandeling Der zee horenkens En zee gewassen in En ontrent, Amboina, Amsterdam 1726, p. 135. Valentjn writes that Ujung Pandang Fortress is called Nykhoek because from here the bay appears and its location at the end.

${ }^{4}$ Harian Kompas, Benteng Pannyuwa, 4 Oktober 1974 h. V 
thus affecting the building. ${ }^{5}$ The fort building that was erected resembled European buildings at that time.

Ujung Pandang Fortress was founded starting with the first layer or wall made of clay and on August 9, 1634 during the reign of King Gowa XIV Tumenanga ri Gaukanna (Sultan Alauddin) given a stone. ${ }^{6}$

The stone is square in shape and irregular in size, like a brick now, as for the size of the brick as follows:

1. The biggest;

Length $=62 \mathrm{~cm}$

Width $=34 \mathrm{~cm}$

Thickness $=20 \mathrm{~cm}$

2. The smallest;

Length $=44 \mathrm{~cm}$

Width $=21 \mathrm{~cm}$

Thickness $=10 \mathrm{~cm}$

This stone consists of sedimentary, andesite stones, arranged in a kind of brick which is thought to have originated from Pangkep-Maros, the kingdom that was subject to the kingdom of Gowa. ${ }^{7}$. Another source said the rock came from the Jeneberang river.

Around the river there is a place called pamangkulang which in Makassar language means cutting, this is where the stones are cut, so that they are shaped into a rectangle and resemble bricks. Meanwhile, the existing buildings in the Dutch fort have used bricks. The brick material comes from Mawang which is now Telaga Mawang which is on the left side of the road to Malino. ${ }^{8}$

To make the walls of Ujung Pandang Fortress, thousands of workers were deployed. All of them were prisoners of war transported from the kingdoms of South and Southeast Sulawesi which were conquered by the Gowa troops. The workers worked day and night. Some were carrying stones by way of the stone being moved from hand to hand so that they arrived at the destination, namely Ujung Pandang Fort.

Based on the description above, it is clear to us that Ujung Pandang Fortress was not founded by the Portuguese as the writer often hears. However, the influence of

\footnotetext{
${ }^{5}$ Ince Nurdin Daeng Magassing in "Babad Celebes" writes as follows: "Ujung Pandang Fortress was made by King Gowa X in 1545 with the guidance of the King of Ternate Chapter Ullah. The building is exactly the same as the Fortress in Europe at that time. Perhaps with the guidance of a Portuguese engineer who was already in Makassar (Gowa) at that time. It is possible for the Makassar people themselves, weren't there already some people who had gone to Europe brought by the Port uguese. After all, in the past, the people of Makassar had a lot of knowledge, medicine for pairs, and made cannons themselves.

${ }^{6}$ Branch Office II of the Institute of History and Anthropology Ujung Perspective, Fort Rotterdam (Ujung Pandang: LSA, 1975), p. 1; quoted in Lontara Bilang, Lontara Andi Mappanyukki, Lontara A. Ijo, Makassar Chrestomatie h. 185, History of the Kingdom of Tallo, p. 17; it is written that the King of Gowa XIV Sultan Alauddin gave the Ujung Pandang Fortress stone. So it is possible that previously the walls of the fortress were made of clay.

${ }^{7}$ Drs. Mohammad Natsir (55 tahun), Kasubag. Tata Usaha Balai Pelestarian Cagar Budaya Sulawesi Selatan, Wawancara, 6 Juli 2020

${ }^{8}$ Drs. Mohammad Natsir, Hasil Wawancara, 6 Juli 2020.
} 
Portuguese architecture on this building cannot be raised because at that time the relationship between the Portuguese and the Kingdom of Gowa already existed, as when it first existed in South Sulawesi, it was Portuguese.

In carrying out their efforts, they experienced many obstacles from the kings and people of the Maluku islands. First the Portuguese conquered Ternate a large and influential kingdom in the Maluku archipelago. There was the seat of a Portuguese governor named "Antonio de Brito" for the Maluku islands. On 25 October 1536 Galvao Antonio became Governor of Ternate. It was only in 1538 that the Port uguese arrived at Somba Opu and for the first time made contact with the King of Gowa IX "Tumaparisi Kallonna”.

During the reign of Karaeng Tumapakrisi Kallonna, the area of royal power began to expand and there began to be progress in all areas. He is the one who makes the laws and regulations of the war, appoints offices or authorities in his district, conducts customs collections and so on to meet government spending needs ${ }^{9}$. Efforts to strengthen the position of the kingdom were pursued by conquest, both through war and by means of pressure on the surrounding countries. When conquered by Garassi, Katingang, Parigi, Siang, Sidenreng, Lembangang, Bulukumba, Selayar, Panaikang, Cempaga, Maros, Polombangkeng and so on ${ }^{10}$ as well as forcing the recognition of the Bugis kings to this power.

The description above shows that during the reign of the king of Gowa IX, there were many wars in the effort to expand the territory of the kingdom, in this situation the Kingdom of Gowa began to recognize a fortress. The development of Makassar as a trading port and defense base began when the king of Gowa IX Daeng Matunru Karaeng Tumapakrisi Kallonna (1510-1546) ordered the relocation of the royal capital from the Tamalate area to the Somba Opu area as the capital. ${ }^{11}$ and the center of government administration and economic activities in the Kingdom of Gowa.

In line with the development of shipping and trade in Southeast Asia, finally a new power emerged in Southeast Asia, namely the Kingdom of Gowa with its capital, Somba Opu, which developed into a large port city. This was supported by the fall of Malacca to the Portuguese in 1511 and the decline of commercial ports in Java so that traders diverted their route to Somba Opu.

Efforts to ensure the security of the kingdom were built fortresses. In several historical sources it is stated that the king of Gowa IX Karaeng Tumapakrisi Kallonna who started the construction of the Kale Gowa fort and the Somba Opu fort from a clay mound and it is stated that almost every king who ruled built a fort or at least provided certain reinforcement to the fort that the king had built. This is what supports why the Kingdom of Gowa has enough fortifications, namely 14, among others ${ }^{12}$ : Benteng

\footnotetext{
${ }^{9}$ Abdul Rasak Daeng Patunru, Sejarah Gowa (Makassar: Yayasan Kebudayaan Sulawesi Selatan dan Sulawesi Tenggara, 1967), h.11.

10 Mattulada, Menyusuri Jejak Kehadiran Makassar dalam Sejarah (Makassar: Hasanuddin University Press, 1991), h. 25

${ }^{11}$ Muhammad Iqbal AM, Peranan dan Faktor yang Berpengaruh Terhadap Penempatan BentengBenteng Kerajaan Gowa Tallo. Dalam Iwan Sumantri (ed). Kepingan Mozaik Sejarah Budaya Sulawesi Selatan. Bagian Proyek Pemanfaatan Peninggalan Sejarah dan Purbakala Sulawesi Selatan, bekerja sama dengan Penerbit Ininnawa. Makassar. 2004. h. 202.

12 Muhammad Iqbal AM, Peranan dan Faktor yang Berpengaruh Terhadap Penempatan BentengBenteng Kerajaan Gowa Tallo. Dalam Iwan Sumantri (ed). Kepingan Mozaik Sejarah Budaya Sulawesi Selatan. h. 202
} 
Somba Opu, Benteng Tallo, Benteng Ujung Tanah, Benteng Ujung Pandang, Benteng Mariso, Benteng Bontorannu, Benteng Panakkukang, Benteng Bayoa, Benteng Garassi, Benteng Barombong, Benteng Kale Gowa, Benteng Ana Gowa, Benteng Galesong, Benteng Sanrobone.

In this era, Daeng Pamatte, a Syahbandar and Tumailalang, also wrote a lontara. Lontara $^{13}$ is an ancient manuscript for the people of South Sulawesi. Some foreigners who have studied Lontara, the history of South Sulawesi and gave their assessments, include Kern and Cense. Kern, who has read old manuscripts in Indonesia, gives an assessment of Lontara as a historical source of South Sulawesi, in his words, the Bugis and Makassarese people have different views which deviate from the views of other tribes in the archipelago. the Bugis-Makassarese people are interested in historical events themselves and they write them with complete confidence. Because of this, the view of their soul which is peculiar to that which was revealed in the beginning of history, is important enough to give a Bugis a chance to speak to prove it. ${ }^{14}$

Meanwhile, Cense, a Dutchman who had made a Lontara collection while working in Makassar, stated that the Matthes Foundation in Makassar before the war had collected many historical texts, proving how much interest the people of South Sulawesi had in the past. Cense's assessment of the contents of Lontara illustrates that if we compare it with what is recorded as historical stories in other parts of Indonesia, our attention is drawn to how simple and real the people of South Sulawesi are in the way they record facts and process the material. In fact, being rational is characteristic of the literature of the people of South Sulawesi, whereas Cense, a Dutchman who had collected the Lontara collection while working in Makassar, stated that the Matthes Foundation in Makassar before the war had collected many historical texts, which proves how much great interest in the population of South Sulawesi in the past. Cense's assessment of the contents of Lontara illustrates that if we compare it with what is recorded as historical stories in other parts of Indonesia, our attention is drawn to how simple and real the people of South Sulawesi are in the way they record facts and process the material. In fact, being rational is a characteristic feature of South Sulawesi literature.

Based on the Lontara records from the Kingdom of Gowa, finally an agreement was reached between the Company and Sultan Hasanuddin which reads:

"Kuuwea top aiyro arueG aiy eakeaew ri suerea jciwi aeln et mkuelai npir and ecpea ri buGea et mkuel toai nkurGi aiy mua njciaGi aeln mesrieaGi and ecpea ri buGea pur nwiruea Admiral Speelman silao sob sobea ri tau 1667 ri 18 eaern noepeber."

"Kuwaé topa iyaro arungngé iya engkaéwé ri sure'é janciwi aléna teng makkulléi napinra adanna ceppaé ri Bungaé teng makkullé toi nakurangi iya mua

${ }^{13}$ Lontara is a written source that describes the situation of the people of South Sulawesi, which began in the XIV century. It is called Lontara because it is written on palm leaves. See Mattulada "Pra Islam South Sulawesi", dalam Universitas Hasanuddin, VI-XVII (Juli 1975), h. 4.

${ }^{14}$ Syamzan Syukur, "Islamisasi Kedatuan Luwu pada Awal Abad XVII", Disertasi (Jakarta: UIN Syarif Hidayatullah, 2008), h. 17. dikutip dalam R.A. Kern, Proeve van Boeginesche Geschiedschrijving, Bijdrage tot de Taal-Land-, en Volkenkunde 104. S'Gravenhage, 1948, h. 30. 
najjanciangngi aléna masseriéngngi adanna ceppaé ri Bungaé pura nawinru'é Admiral Speelman silaong somba-sombaé ri taung 1667 ri 18 éréna Nopember."15

Meaning:

Likewise, the king who is in his letter of agreement cannot change his words in the bungaya. Nor could it be deducted from what was promised to him, which had already been tied to his words in Bungaya, which Admiral Speelman had compiled with the kings in 1667 on 18 November.

After several serious negotiations between Speelman and his allies with the Sultan and government officials on the other side, finally on Friday 18 November 1667 an agreement was reached at a place called Bungaya near Barombong. The agreement is known as "Cappaya ri Bungaya".

The agreement was the basis for the Dutch to plant and further strengthen colonialism in South and Southeast Sulawesi in particular and East Indonesia in general.

As a result of the sacrifice of the Bungaya agreement between the Kingdom of Gowa and the Dutch (VOC), Sultan Hasanuddin forced Sultan Hasanuddin to destroy all the fortresses of the Gowa kingdom on the coast of the Makassar strait except Ujung Pandang Fort which was intended for the Dutch and the Somba Opu fort which was intended for the kingdom of Gowa. ${ }^{16}$

The contents of the Bungaya agreement agreement ${ }^{17}$ Article 11 that the Ujung Pandang fortress together with the land including its environment will be handed over to the Company. The company lodge will be rebuilt. Based on article 11, since the signing of the Bungaya Agreement, the Ujung Pandang fortress transferred to the Dutch company. On November 18, 1667, Speelman began living in Fort Rotterdam, cannons were placed on the walls, armor was prepared for both defense and attack and remodeled all the buildings in the fort with colonial architectural styles.

Somba Opu Fortress as the stronghold of the capital city of the kingdom which functioned as the center of government, economy and trade became the last stronghold of the Gowa kingdom which was destroyed two years after the Bungaya agreement after going through a considerable war. ${ }^{18}$. Meanwhile, Ujung Pandang Fort became the property of the Dutch Company and changed its name to Fort Rotterdam.

The following reviews the location, area, height, shape and meaning of Ujung Pandang Fortress (Pannyuwa):

\section{B. Location, area, height of Ujung Pandang Fort}

Ujung Pandang Fortress is located on the seafront in the middle of Makassar city from north to south. Overall, the area of Fort Rotterdam is $28,595.55 \mathrm{~m} 2$ and the total area of the building is $11,805.85 \mathrm{~m} 2$. The fort has a rectangular basic plan, with a large

15 Lontara Kerajaan-kerajaan di Sulawesi dan Perjanjiannya dengan Kompeni-kompeni, manuskrip, (Makassar: Dinas Perpustakaan dan Kearsipan Provinsi Sulawesi Selatan), h. 8.

${ }^{16}$ Mattulada, Menyusuri Jejak Kehadiran Makassar dalam Sejarah 1510-1700, cet. I (Makassar: Bhakti Baru-Berita Utama, 1982), h. 86.

${ }^{17}$ The Bungaya Agreement (often called Bongaya or Bongaja) is a peace agreement signed on 18 November 1667 in Bungaya between the Sultanate of Gowa represented by Sultan Hasanuddin and the Dutch East Indies represented by Admiral Cornelis Speelman.

18 Mattulada, Menyusuri Jejak Kehadiran Makassar dalam Sejarah, h. 92. 
door on the west facing the sea and a small door on the east. The highest part of the wall is $7 \mathrm{~m}$ and the lowest part is $5 \mathrm{~m}$ with a wall thickness of $2 \mathrm{~m}$.

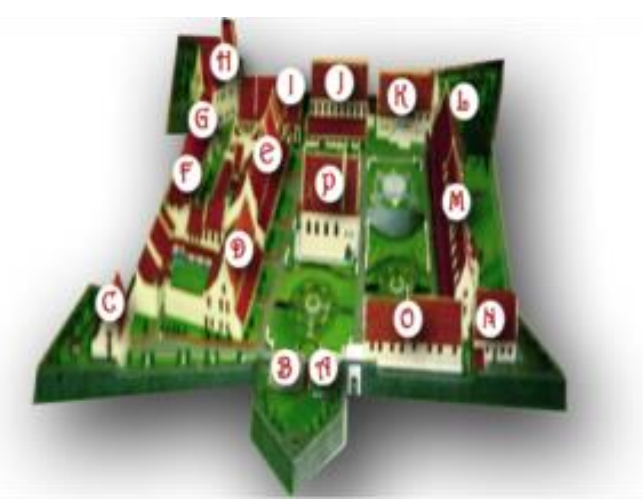

Figure 1. Plan of Fort Rotterdam

(Source: South Sulawesi Cultural Heritage Conservation Center)

There are 16 buildings inside the fort, including a security post building (a), a tourist guide building (b), the Makassar arts council (c), the La Galigo museum (a collection of historical heritage) (d), an office for the Preservation of Reserves. Culture (e), museum collection warehouse space (f), South Sulawesi painter's activity place (g), guest house (h), Japanese heritage object storage (i), library (j), headroom of the Cult ural Heritage Preservation Center (k), workshop room and office equipment for the Preservation of Cultural Heritage (1), La Galigo museum (collection of human cultural products) (m), La Galigo Museum office in South Sulawesi Province and Prince Diponegoro detention room (n), audio visual object room cultural heritage (o) and the office hall of the Cultural heritage Conservation Center and exhibition hall for the collection of cultural heritage objects (p). Currently several buildings in the fort are used as offices by the Makassar Cultural Heritage Conservation Center, namely Buildings B, I, K, L, O, P, J and building E. All of these buildings were built by the Dutch except for building I built by the Japanese.

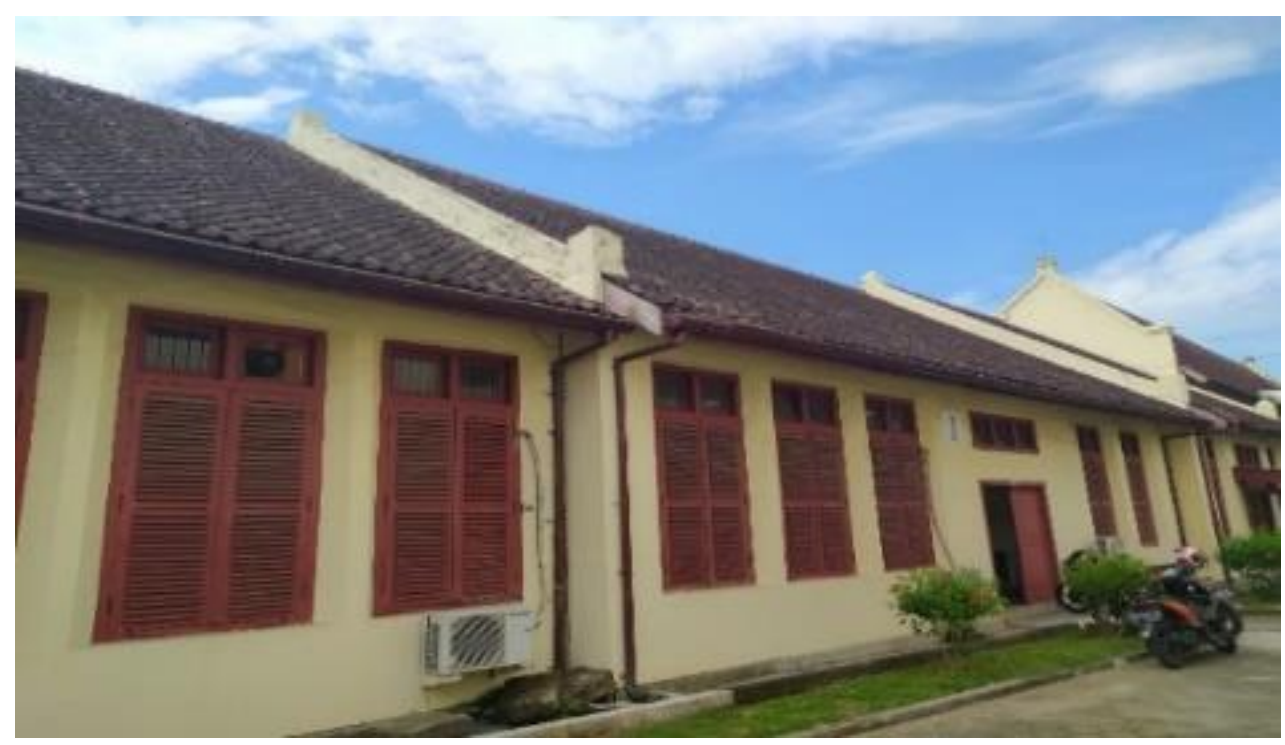

Picture. 2 Japanese buildings seen from the side 


\section{Form and Meaning of Ujung Pandang Fortress (Pannyuwa)}

Ujung Pandang Fortress has a special shape like a turtle that is crawling down to the sea. Ujung Pandang Fortress has a shape similar to the forts built in the 16th cent ury, XVII such as Fort Amboina, Banda Batavia, Malacca which is square in shape ${ }^{19}$.

The difference between the Ujung Pandang fort and the forts is the protrusion of the back as the tail, so the people of Makassar call it Pannyuwa Fort (Turtle Fortress). As for the interpretation of the turtle-shaped background, the source is only obtained from mouth to mouth, namely:

1. Turtles live and seek life in the sea and lay their eggs on land. This is interpreted as the courage and heroism of the Gowa people at sea and glory on land. There are also those who interpret the Gowa people as living on land and earning a living in the sea.

2. Sea turtles lay many eggs but secretly meaning the people of Gowa do a lot of work but do not talk much and for many people.

Turtles have a strong and hard back to protect themselves, interpreted Ujung Pandang Fortress as a protector for the people and government of Gowa. ${ }^{20}$

\section{Preservation of Fort Rotterdam Post-Bongaya Agreement}

After the bongaya agreement in Fort Rotterdam there have been many historical events including; First, it was used as the center of the VOC government even though its government took the form of a trade association instead of the Dutch East Indies government. VOC started from Somba Opu and was the 6th largest trading port in the archipelago so that foreign traders made Makassar a transit city from East to West, especially in the spice trade efforts. Second, used as a place to live. When it was used as a residence, the fort building was changed, originally the fort was traditional Makassar buildings, Makassar architecture made of wood and so on. ${ }^{21}$

When it was founded by the Kingdom of Gowa, except for the fort walls made of earth, brick. When the Dutch entered and made it the VOC trade center, the fort buildings were replaced as seen today. It was built during the Dutch era, including strengthening the walls of the current fort by using solid stones in the shape of large boxes. When they built they must have built according to their needs, namely to become a trading center.

After the Dutch occupation, the Japanese entered Indonesia, but the role of the fort was no longer a place of defense but as a center for language and agricultural research. Then when the transitional period of independence, Fort Rotterdam was vacated and in 1970 it was used as a dormitory for young soldiers.

This shows that there has been a deprivation of function experienced by the historic building following the prevailing rulers and times, now the fort is no longer used as a center of defense and so on. The first law regulating conservation is the monumenten ordinance Law No. 238 in 1931 by the Dutch. ${ }^{22}$ However, the law no longer applies after a post-independence takeover. Then in 1973 the government of South Sulawesi

19 Aisyah Dampoli, "Peranan Benteng Ujung Pandang dalam Sejarah Gowa", Skripsi (Ujung Pandang: UNHAS, 1974), h. 48.

${ }^{20}$ Kantor Cabang II Lembaga Sejarah dan Antropologi Ujung pandang, Benteng Rotterdam, h. 5.

${ }^{21}$ Drs. Mohammad Natsir, Hasil Wawancara, 6 Juli 2020.

22 Drs. Mohammad Natsir, Hasil Wawancara, 6 Juli 2020 
established the 4th National Archaeological Heritage Institute that since then the state institution has been in charge of the Citadel. The Governor of South Sulawesi declared the fort as the cultural center of South Sulawesi, including all the offices in charge of culture, including the language office, archives, libraries, historical studies centers, publications, and museums. ${ }^{23}$

After that, according to the letter of the head of the Antiquities Service dated April 4, 1953 / No. 504 / D 4, among other things, stated that if before the war these rooms were occupied by civilian government services then after the war that in principle only cultural enterprises could be located inside Fort Rotterdam. The letter was strengthened by the decree of the Minister of Education and Culture of the Republic of Indonesia No, 014 / A / 1/1974 concerning the designation of Ujung Pandang Fortress as the "cultural center" of Ujung Pandang and the formation of its guidance council. ${ }^{24}$

\section{E. As a Cultural Development Center}

Ujung Pandang Fortress as a center for cultural development is really being utilized. We can see this in cultural activities centered in Ujung Pandang Fort. In 1974 a stage for performing arts in the middle of the field in Ujung Pandang Fortress has been built, since this stage has been carried out many activities such as dance competitions, monks, drama performances, exhibitions, arts, ancient times, art parades and so on. . Besides these activities, we can also see that the buildings in Ujung Pandang Fortress are used by agencies engaged in culture as follows:

1. Office of the Department of Education and Culture of the South Sulawesi Region for the Arts.

2. National Archives Office.

3. La Galigo Museum.

4. The Office of the Institute for Antiquities and National Heritage (LPPN) later became a Cultural Reserve and is now a Cultural Heritage Conservation Center.

5. Office of the Institute for History and Anthropology.

\section{F. Fort Rotterdam as a Tourist Object ${ }^{25}$}

And finally, the management of historical relics is regulated by the Constitution No. 11/2010. RI Law No.11 of 2010 concerning cultural heritage is the result of a revision of RI Law No.5 of 1992 concerning cultural heritage objects. Based on the contents of Law No. 5/1992, preservation of cultural heritage is still central, meaning that the obligation to preserve cultural heritage is still the government's obligation. However, with the Republic of Indonesia Law No.11 of 2010 which stipulates that every individual is obliged to protect existing cultural heritage. Thus, it will encourage the emergence of community participation in preserving cultural heritage.

\footnotetext{
${ }^{25}$ Kantor Cabang II Lembaga Sejarah dan Antropologi Ujung pandang, Benteng Rotterdam, h. 34-35.
}

${ }^{23}$ Drs. Mohammad Natsir, Hasil Wawancara, 6 Juli 2020

32.

${ }^{24}$ Kantor Cabang II Lembaga Sejarah dan Antropologi Ujung pandang, Benteng Rotterdam, h. 
Fort Rotterdam is the only defensive fortress of the XVI century in our homeland which is a historical monument that is still intact in such a way, an example of the quality of the ingenuity of building our ancestors in the XVI century which is rather contrasting is that it contains buildings with regional patterns but the buildings typical of Europe in the XVII century. What is interesting for foreign tourists to come to Fort Ujung Pandang (Fort Rotterdam) which contains an interesting collection of archaeological and ethnographic history.

\section{CONCLUSION}

Ujung Pandang Fortress together with other forts stand majestically along the coast of the Kingdom of Gowa. One of the strengths of the Gowa Kingdom lies in its defense. Therefore the Dutch saw the Gowa fortress as a source of Gowa's strength. So one way to paralyze the strength and defense of Gowa was to destroy all the forts in the Kingdom of Gowa, except for the Ujung Pandang fortress because it was used as a fortress and the center of government for the Dutch Company. This proves that of the many forts in the Kingdom of Gowa, the only Ujung Pandang Fortress which we can still see today is known as Fort Rotterdam.

Before being occupied by the Dutch, Ujung Pandang Fortress contained buildings that were typical of Makassar houses, which were high pillars and made of wood. On November 21, 1667, after the Bongaya Agreement Speelman lived in Ujung Pandang, from then on the fort was controlled and occupied by the Dutch for several centuries until the entry of the Japanese in Indonesia. Then the name of Ujung Pandang Fortress became Fort Rotterdam which is the birthplace of Speelman in the Netherlands. The role of Fort Rotterdam before the Makassar war had its rooms occupied by civilian government agencies so after the war that in principle only cultural businesses could be placed in Fort Rotterdam based on the decree of the Minister of Education and Culture of the Republic of Indonesia in 1974 that stipulated the Ujung Pandang Fortress as a center for cultural development and as a tourist attraction that contains collections of archaeological and ethnographic histories that attract domestic and foreign tourists.

\section{DAFTAR PUSTAKA}

Dampoli, Aisyah. "Peranan Benteng Ujung Pandang dalam Sejarah Gowa". Skripsi. Ujung Pandang: UNHAS, 1974.

Daeng Patunru, Abdul Rasak. Sejarah Gowa. Makassar: Yayasan Kebudayaan Sulawesi Selatan dan Sulawesi Tenggara, 1967.

Francois, Valentjn. verhandeling Der zee horenkens En zee gewassen in En ontrent, Amboina, Amersterdam 1726

Gunadi, "Retrospeksi. Pengelolaan Sumberdaya Budaya: Studi Kasus tentang Upaya Pelestarian Sumberdaya Budaya di Makassar". Kantor Wilayah Departemen 
Pendidikan dan Kebudayaan Provinsi Sulawesi Selatan: Majalah Dunia Pendidikan, No 15, 16, 17, 2001.

Iqbal AM, Muhammad. Peranan dan Faktor yang Berpengaruh Terhadap Penempatan Benteng-Benteng Kerajaan Gowa Tallo. Dalam Iwan Sumantri (ed). Kepingan Mozaik Sejarah Budaya Sulawesi Selatan. Bagian Proyek Pemanfaatan Peninggalan Sejarah dan Purbakala Sulawesi Selatan, bekerja sama dengan Penerbit Ininnawa. Makassar. 2004.

Kompas, Harian. Benteng Pannyuwa, 4 Oktober 1974 h. V

Kantor Cabang II Lembaga Sejarah dan Antropologi Ujung pandang. Benteng Rotterdam. Ujung Pandang: LSA, 1975.

Lontara Kerajaan-kerajaan di Sulawesi dan Perjanjiannya dengan Kompeni-kompeni. Manuskrip. Makassar: Dinas Perpustakaan dan Kearsipan Provinsi Sulawesi Selatan.

Mattulada. Menyusuri Jejak Kehadiran Makassar dalam Sejarah. Makassar: Hasanuddin University Press, 1991. 1975).

------------. Menyusuri Jejak Kehadiran Makassar dalam Sejarah 1510-1700, cet. I. Makassar: Bhakti Baru-Berita Utama. 1982.

Nuraeda, dkk., Album Sejarah dan Kepurbakalan Sul-Sel Wisata Kultural Historis. Makassar: Dinas Kebudayaan dan Pariwisata Provinsi Sul-Sel, 2008.

Risang. A dan Dhani Mutiari. Karakteristik Benteng Vastenberg sebagai Bangunan Heritage di Surakarta. journal UMS, 2018.

R.P, Soejono. Sejarah Nasional Indonesia I. Jakarta: Balai Pustaka, 1984.

Syukur, Syamzan. "Islamisasi Kedatuan Luwu pada Awal Abad XVII". Disertasi. Jakarta: UIN Syarif Hidayatullah, 2008. 